\title{
Research on the Departure Effect of the Growth Enterprise Market Listing Corporation Executives
}

\author{
Zhiyang Li \\ School of Economics, Jinan University, Guangzhou, China \\ Email: 1204378429@qq.com
}

Received 21 December 2015; accepted 25 January 2016; published 28 January 2016

Copyright (C) 2016 by author and Scientific Research Publishing Inc.

This work is licensed under the Creative Commons Attribution International License (CC BY). http://creativecommons.org/licenses/by/4.0/

(c) (i) Open Access

\begin{abstract}
In our country, the GEM Listing Corporation executives are usually the founder of the company, so the departure of them will have a significant impact on the company and the market. While in the past, most of the literature focuses on the factors of the turnover of the executives, the influence of the senior executives' turnover on the capital market is rare. We selected executive turnover data from 2009 October 30 (GEM Listing Date) to 2014 December 30, using the event study method of the Chinese stock market effect, and drawing the conclusion: GEM listed company executives turnover on the stock market effect is not the information effect or the true effect, but the cash effects; although executive turnover will produce cash effect on the market, after calculation, according to incomplete statistics results only about half of the executives is in cash precise turnover, cash index is not high. So the conclusion is that resignation of senior management cash only part of the phenomenon, but it is enlarged by the market, having obvious effect of cash.
\end{abstract}

\section{Keywords}

The Departure Effect, The Information Effect, The True Effect, The Cash Effects

\section{Introduction}

GEM is established for financing and developing of the venture capital enterprises, small and medium enterprises and high-tech industry enterprises and others. On the one hand, it can increase the liquidity of the shares of innovative enterprises and facilitate the implementation of equity incentive plan, encouraging employees to participate in enterprise value creation, on the other hand, it will bring the agency costs and adverse selection. According to www.xinhuanet.com reported, the resignation of senior executives of the Listing Corporation 
mainly concentrated in the small board and GEM companies announced on February 2015, the total turnover in all 407 executives, 213 people came from the small board and GEM companies. According to the Tai'an database, as of November 31, 2015, there were 314 cases of the GEM Listing Corporation executives turnover of China. It is worth noting that the GEM Listing Corporation executives turnover phenomena do not just appear in this year, back in October 30, 2009 the first batching of 28 companies officially listed on the Shenzhen Stock Exchange, less than a month after the November 26, 2009, the new Ning logistics (300013) released Mr. Sun Bing resigned as an independent director of the company's announcement, the GEM Listing Corporation executives departure of cash are rampant. There were 156 executives leaving from 153 companies which had been listed on GEM by the end of 2010. Although in November 4, 2010, the Shenzhen Stock Exchange issued new regulations, 148 executives left from 282 companies which had been listed by the end of 2011 and at the end of 2012 the cases had reached 434. Executives play an important role in the establishment and implementation of the development strategy of the company, especially the GEM Listing Corporation executives. We study on behalf of executives including directors and supervisors, managers and securities affairs in this paper. Separation is a major event in the company [1]. More and more attention is paid to the company executives (executive, in this paper, are defined as the company's directors, supervisors and general managers) of the separation problem.

Seeing that the GEM Listing Corporation executives departure phenomenon is very common, what problem will bring to the market is the investors and researchers' common concern. There are few studies on the empirical research on the effect in recent years. They mainly consider two aspects of the stock market: the information effect and the real effect of the impact by using the event study method. The information effect is that the company's performance is lower than market expectations and the negative reaction [2]; the real effect is caused by the maximization of shareholders' interests, and the replacement of senior executives will have a significant positive effect [2]. This paper, combined with previous studies, focuses on the effect of the resignation of executives. On the background of GEM, we try to separate the departure executives to shareholders and non-shareholders. We share the introduction of arbitrage effect of this new concept of the market and the effect of the market caused by focusing the market, a targeted analysis, pulling-in the new concept of arbitrage effect on the concentration of executives.

\section{Prior Literature}

There are many research in the topic on the executive turnover at home and abroad, but because of the GEM is set up about 6 years the research on the executives turnover is not many. The existing literature is focused on the factors which affect the turnover. Kang and Shivdasani [3] firstly proposed that the company performance worse, executive turnover probability is bigger, then some scholars put forward the internal corporate governance problems which will cause the executive turnover in China; scholars Yuchi Gong [4], Hongjun Zhu [5] Tingqiu Cao, Guangli Zhang [6] from business performance, corporate governance, remuneration of executives of Tao He [7] studies from the company have private equity investment, Ruocan Wang, Haiyan Xiang [8] combined the process and the essence of the development of organization and the gem of our company, analysing the four aspects of vulnerability incentive plan from the rationality of choice, equity is not perfect, the legal norms of the capital market and the weak effectiveness. But there is no further research on the impact of the GEM capital market.

Hillier et al. [9] studied the negative reaction to the market, and there were many articles about the relationship between the executive turnover and market reaction. Jensen \& Warner [10], Bonnier \& Bruner [11] Suchard, Singh \& Barr (2001) [12] all showed that the stock market reaction is the comprehensive and trade-off of the information effect and the real effect. The definition of these two effects, Warner [2] has long been given: information effect is that the top executives replace the company performance is lower than market expectations, senior executives replacement event will be this kind of negative information to the market, the market to make negative reaction; and true effectiveness should be referred to the company's internal governance mechanism for the purpose of maximizing shareholder interests, will be a significant positive effect on executive replacement. In China, Xiaofeng Quan, Shinong Wu [13] also analyzed the information effect and the real effect of the game through theoretical and empirical analysis, then give the reason for the departure of executive turnover. In fact, Kunyuan Qiao [14] proposed by executives is mainly due to the adverse effects of moral hazard effect brings to the company's performance of the year with all different approaches but equally satisfactory results and arbitrage risk. And the Securities Daily reporters found that the effect of executive turnover on the GEM is to a cer- 
tain extent, is not representative after collating and analyzing the information .So in case of the exclusion of individual agents make the error of Overgeneralization, this paper attempts to make an empirical analysis of the market. At the same time, Yuechun Wen, Yibing Duan [15] using the event research method to study the impact of senior executives on the market stock, and draw conclusions: in the short term, the impact on the stock price is not obvious, but the long-term will have a negative impact on the stock price, and the impact of the event before and after the event is the largest of the 15.

In order to identify the impact of the event, if the event has a negative impact on the market, note that the information effect; if the market has a negative impact, in order to identify what is the effect in this paper, refer to Lili Pi, Chao Zhao [16], Zhang Ming [17], in accordance with whether or not equity this classification approach, in accordance with executives. Whether or not. If you do not share this classification. In accordance with the empirical correlation. If the results are positive, the market has a significant negative effect on the market, not holding the resignation of executives to the market reaction is not obvious, it is proved to have a cash effect on the market.

This paper is inspired by Tingqiu Cao, Guangli Zhang [6], expecting to have a further study of whether executives are accurate to leave to cash, trying to build a cash function to calculate the optimal time point or period.

\section{Research Design}

\subsection{Sample Selection}

The date of this article from the initial opening of the GEM in China to December 31, 2014 was obtained from the Tai'an database. We got 625 executives turnover data, these former executives from 197 GEM Listing Corporation in order to get the effective sample. The original samples were selected according to the following standard: 1) We deleted financial listing corporation sample; 2) We removed all ST and PT samples during the sample period; 3) We removed the resignation announcement within 10 days before the disclosure of other major events announcement samples. These events included the announcement of dividends, shares, mergers, equity change, shares announcement that the samples were deleted in order to get the clean sample, we got 197 announcement; 4) We deleted abnormal samples. After the deletion process, we finally get 135 notice events in this paper, including the announcement of the resignation of 64 shareholder executives and 71 non-shareholder.

\subsection{Research Design}

Firstly, this paper, referring to the practice of Changyun Wang, Chengsi Zhang (2010), made the choice of executive resignation announcement day $\mathrm{t}=0$, the event window is $[-10,10]$, the estimated window is $[-100,-30]$, ex-post window is [10, 30], that is, 100 days before the date of the announcement of the 117 trading days as an estimated window, with all 90 companies in the first 10 days of the corresponding market return data.

Secondly, determine the normal and abnormal return rate. Hanwen Chen and Xiangmin Chen (2002) chose 951 companies which listed from 1990 to 2000 in Shanghai and Shenzhen as a sample, testing the effect of the mean adjusted model, the market model and the model of market adjustment, the results showed that there is some limitations of the market model and advantage of the mean adjustment model in the Chinese market. The model also includes CAPM model, APT model, Carhart model and four factor model. But Brown and Weinstein (1985) showed that these economic models had no practical advantages compared with the non-restricted. So the market model is the most widely used model: $E R_{i t}=\alpha_{i}+\beta_{i} R_{m t}\left(E R_{i t}\right.$ represents the stock return rate of I in T, and $R_{m t}$ is the stock return of the market portfolio at $t$.)

In view of the above reasons, this paper will use the market model to calculate the normal rate of return, abnormal return is defined as:

$$
A R_{i t}=E R_{i t}-\alpha_{i}-\beta_{i} E R_{m t}
$$

Thirdly, parameter estimation. The use of each stock after the ex-dividend price logarithm difference before and after the two to calculate $E R_{i t}$, similarly we can get $E R_{m t}$, where $P_{i t}$ is the securities it time right after the re closing price, $P_{m t}$ is the GEM index at the time of T's closing price. Formula yields are as follows:

$$
\begin{gathered}
E R_{i t}=\ln P_{i t}-\ln P_{i t-1} \\
E R_{m t}=\ln P_{m t}-\ln P_{m t-1}
\end{gathered}
$$


$\alpha_{i}$ and $\beta_{i}$ are estimated by estimating the window data, using this parameter in the event window to calculate the abnormal return rate ARit. CAR is defined as the abnormal return rate of the sample as a whole, ACAR is the average abnormal return rate of the event window:

$$
\begin{aligned}
& C A R=\sum_{t=1}^{n} C A R_{t} \\
& C A R_{t}=\sum_{i=1}^{n} C A R_{i t} \\
& A C A R=C A R / n
\end{aligned}
$$

\section{Results and Discussion}

From Figure 1, it can be seen that the stock price is not significantly affected by the senior executive turnover, which has neither negative information effect nor positive real effect.

This is inconsistent with the previous research conclusions, inspired by Tingqiu Cao [6] is paper further divides the turnover executives into two types of stock ownership and non shareholder analysis, from Figure 2 we found in the $t=1$ after the decline in the stock price from 3 days to tenth days are down, the negative effect is very obvious.

Then we found that the stock price with no stock holdings executives leave is little, see Figure 3.

It is not difficult to see the cash effect of the executives to leave the market through these three charts, in order to get further evidence, this paper tries to get the regression results of the three cases, see Table 1.

The regression of all the turnover executives and non-stockholder executives is not significant, only the $1 \%$ confidence level, and the model interpretation is the highest, the effect is negative, which is consistent with the above conclusion: GEM Listing Corporation executives leave the market will bring the market cash effect.

Empirical research found that the GEM executives leave the market will have a significant cash effect, but in the perspective of executives, they are really the purpose of the separation of cash? To this end, this paper attempts to establish a simple model of executive turnover or not based on the departure time.

By the above formula we known that before 4 November 2010, if you want to get cash effect, you must

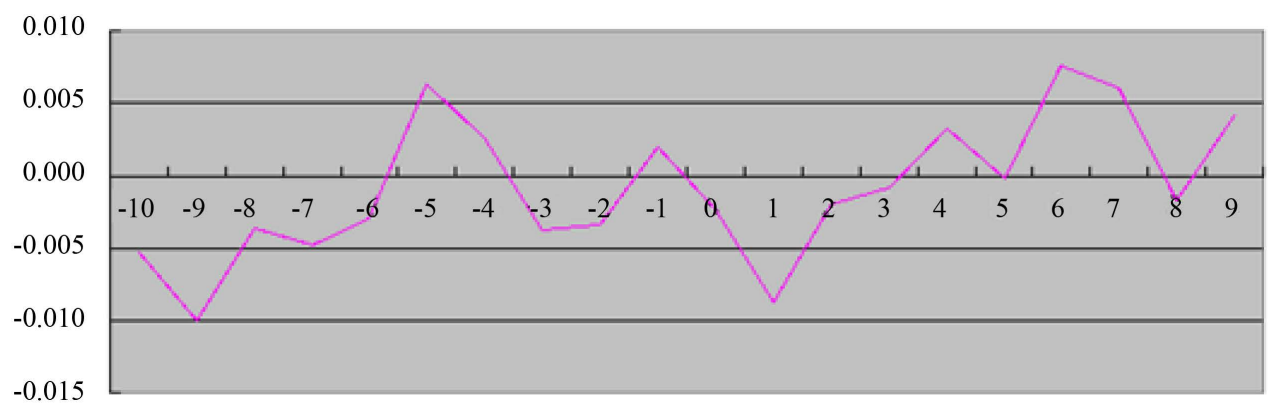

Figure 1. CAR of executive departure.

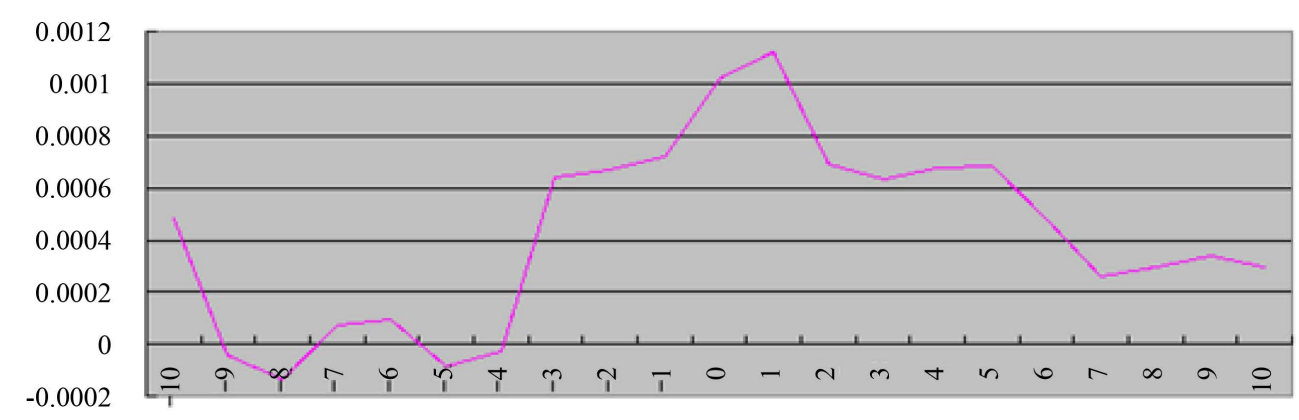

Figure 2. CAR of shareholder executive departure. 


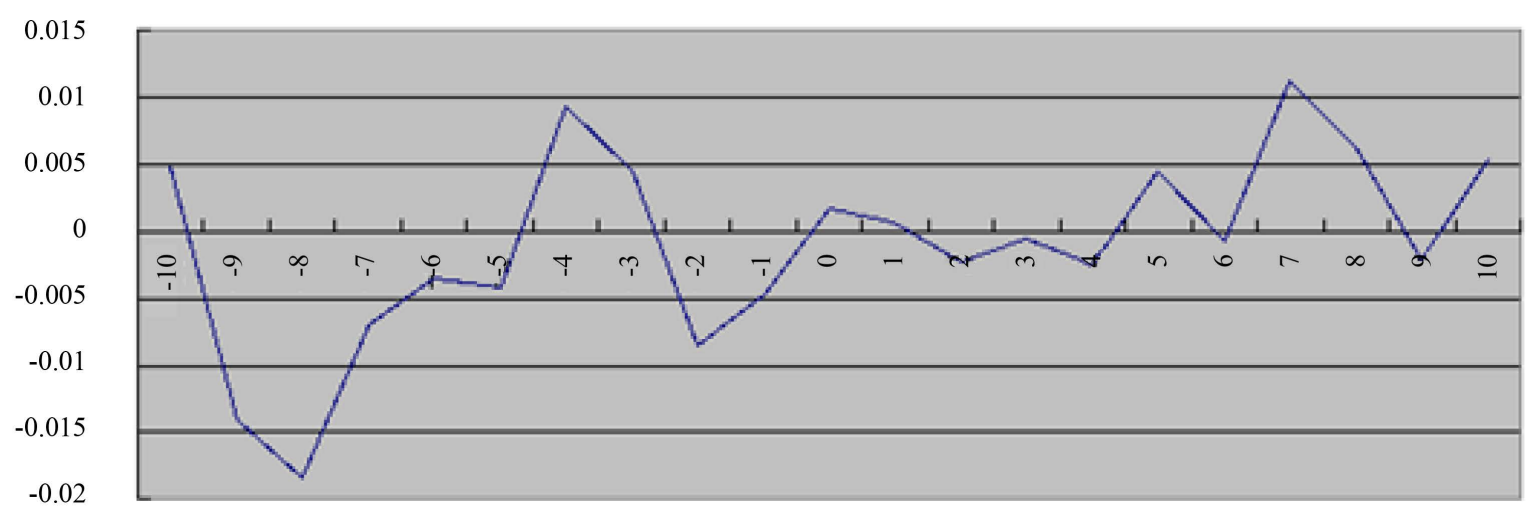

Figure 3. CAR of non-shareholder executive departure.

Table 1. The effect of executive turnover announcement.

\begin{tabular}{cccc}
\hline & $\mathrm{R}$ & $\mathrm{R}$ & $\mathrm{R}$ \\
\hline $\mathrm{Rm}$ & 0.953 & $1.525^{* * * *}$ & $(0.697)$ \\
& $(0.11)$ & $(4.65)$ & \\
Share & & $-0.0795^{* * *}$ & $(-3.37)$ \\
Non-share & & & -0.0063 \\
$\mathrm{R}^{2}$ & & & $(0.054)$ \\
$\mathrm{N}$ & 0.1905 & 0.4998 & 0.1246 \\
\hline
\end{tabular}

turnover within 2 years after listing, and after 4 November 2010 set period is within 1 years after listing (Table 2)

$$
\Rightarrow \begin{cases}\left(t_{1}+2.5\right)-\left(t_{2}+0.5\right)=t_{1}+t_{2}+2, & \text { Before reform } \\ \left(t_{1}+2.5\right)-\left(t_{2}+1.5\right)=t_{1}+t_{2}+1, & \text { After reform }\end{cases}
$$

We downloaded data from November 2009 to January 2015 between the GEM Listing Corporation executives leave the announcement date and the listing date through the Tai'an database. We found that after calculating the difference of these two days is not focused, and less than half of the executives are in cash in the separation. However, some people face executives leave event analysis of their cash, such as May 5, 2015 storm technology executives in the company listed only two months on the resignation, many researchers speculated that this is the first half after the cash to pave the way, but after a half year after the new law cannot be lifted, so these studies will be misleading to investors (Table 3).

\section{Summary and Conclusions}

1) We studied the situation of the turnover of the GEM Listing Corporation in 2009, 2014 in this paper. After excluding other major announcements, we use the market model to calculate the excess return rate. From the overall view of the sample, the market reaction to the resignation of executives is uneven, but only a significant effect of the stock market has a significant effect on the stock market.

2) We further study that the executives' motivation is cash, through a simple calculation of cash, according to incomplete statistics, only about half of the executives are in the cash period to leave, so the cash index is not high. At the same time, the November 4, 2010 law to amend the cash space is very small, so the argument is not true executives leave to cash.

3) It is only part of the phenomenon that the executives leave to cash, but the market is enlarged to have obvious 
Table 2. The effect of senior executives’ turnover on stock price.

\begin{tabular}{|c|c|c|c|c|c|c|}
\hline \multirow{2}{*}{$\begin{array}{c}\text { Event } \\
\text { date }\end{array}$} & \multicolumn{2}{|c|}{ Executive departure } & \multicolumn{2}{|c|}{ Shareholder executive departure } & \multicolumn{2}{|c|}{ Non-shareholder executive departure } \\
\hline & CAR & $\mathrm{t}$ & CAR & $\mathrm{t}$ & CAR & $\mathrm{t}$ \\
\hline $\mathrm{t}=-10$ & -0.0050 & -0.9135 & 0.0005 & 0.1782 & 0.0049 & 0.8054 \\
\hline $\mathrm{t}=-9$ & -0.0150 & -1.8886 & 0.0000 & -1.2992 & -0.0140 & -1.7981 \\
\hline $\mathrm{t}=-8$ & -0.0186 & -0.5636 & -0.0001 & -1.5523 & -0.0184 & -2.4011 \\
\hline $\mathrm{t}=-7$ & -0.0234 & -0.7956 & 0.0001 & -0.9646 & -0.0070 & -0.8284 \\
\hline $\mathrm{t}=-6$ & -0.0264 & -0.4395 & 0.0001 & -0.9199 & -0.0035 & -0.3440 \\
\hline $\mathrm{t}=-5$ & -0.0200 & 1.4946 & -0.0001 & -1.4193 & -0.0042 & -0.4506 \\
\hline $\mathrm{t}=-4$ & -0.0174 & 0.7142 & 0.0000 & -1.2506 & 0.0093 & 1.4170 \\
\hline $\mathrm{t}=-3$ & -0.0212 & -0.5879 & 0.0006 & 0.6016 & 0.0045 & 0.7592 \\
\hline $\mathrm{t}=-2$ & -0.0245 & -0.5127 & 0.0007 & 0.6889 & -0.0086 & -1.0525 \\
\hline $\mathrm{t}=-1$ & -0.0225 & 0.5910 & 0.0007 & 0.8327 & -0.0048 & -0.5266 \\
\hline $\mathrm{t}=0$ & -0.0249 & -0.3010 & 0.0010 & 1.6641 & 0.0018 & 0.3794 \\
\hline$t=1$ & -0.0336 & -1.6222 & 0.0011 & 1.9398 & 0.0006 & 0.2184 \\
\hline$t=2$ & -0.0356 & -0.2363 & 0.0007 & 0.7475 & -0.0022 & -0.1712 \\
\hline$t=3$ & -0.0364 & 0.0261 & 0.0006 & 0.5796 & -0.0005 & 0.0647 \\
\hline $\mathrm{t}=4$ & -0.0332 & 0.8451 & 0.0007 & 0.7023 & -0.0025 & -0.2144 \\
\hline$t=5$ & -0.0334 & 0.1341 & 0.0007 & 0.7283 & 0.0044 & 0.7455 \\
\hline$t=6$ & -0.0258 & 1.7479 & 0.0005 & 0.1411 & -0.0007 & 0.0362 \\
\hline $\mathrm{t}=7$ & -0.0198 & 1.4319 & 0.0003 & -0.4613 & 0.0112 & 1.6742 \\
\hline $\mathrm{t}=8$ & -0.0215 & -0.1759 & 0.0003 & -0.3492 & 0.0061 & 0.9784 \\
\hline $\mathrm{t}=9$ & -0.0173 & 1.0518 & 0.0003 & -0.2316 & -0.0022 & -0.1638 \\
\hline $\mathrm{t}=10$ & -0.0326 & 0.7963 & 0.0003 & -0.3561 & 0.0054 & 0.8725 \\
\hline
\end{tabular}

Table 3. Lift bantime of turnover.

\begin{tabular}{ccccc}
\hline $\begin{array}{c}\text { GEM listing } \\
\text { time }\end{array}$ & $\begin{array}{c}\text { Lift ban time if not } \\
\text { turnover }\end{array}$ & Departure time & $\begin{array}{c}\text { Lift ban time if turnover } \\
\text { (before 4, April 2010) }\end{array}$ & $\begin{array}{c}\text { Lift ban time if turnover } \\
\text { (after 4, April 2010) }\end{array}$ \\
\hline $\mathrm{t} 1$ & $\mathrm{t} 1+2.5$ & $\mathrm{t} 2$ & $\mathrm{t} 2+0.5$ & $\mathrm{t} 2+1.5$ \\
\hline
\end{tabular}

effect of cash, so investors should be rational in the face of all kinds of information. It is worth to deep analyzing the fundamentals of the company in order to invest but not just consider the factors like executive turnover.

\section{References}

[1] Schoar, B. (2003) Managing with Style: The Effect of Managers on Firm Policies. The Quarterly Journal of Economics. http://www.mit.edu/ aschoar/ceostyle.pdf

[2] Warner, J.B., Watts, R.L. and Wruck, K.H. (1988) Stock Prices and Top Management Changes. Journal of Financial Economics, 20, 461-492. http://dx.doi.org/10.1016/0304-405X(88)90054-2

[3] Kang, J.K., and Shivdasani, A. (1995) Firm Performance, Corporate Governance and Top Executive Turnover in Japan. Journal of Financial Economics, 38, 29-58. http://dx.doi.org/10.1016/0304-405X(94)00807-D

[4] Gong, Y.C. (2001) Company Performance and High Level Replacement. Economic Research, No.10, 75-96.

[5] Zhu, H.J. and Yu, L. (2003) The Wealth Effect of the Replacement of Senior Executives. Beijing: Economic Science, No. 4, 85-94.

[6] Zhang, G.L. and Cao, T.Q. (2012) Research on the Motivation and Effect of the Listing Corporation Executives to Resign. Economic Research, No. 6, 73-87.

[7] He, T. (2013) On the Relationship between PE and the Shareholders of the Company Executives to Resign the Influen- 
tial. Journal of South China University of Technology, No. 6, 29-35.

[8] Wang, R.C. and Hai, Y. (2013) GEM Listing Corporation Executives Resigned for Cashing the Reason and Countermeasures of Modern Commercial. Modern Business, No. 21, 63-64.

[9] Hillier, D., Marshall, A, McColgan, P. and Werema, S. (2006) Company Performance Surrounding CEO Turnover: Evidence from the UK. Working Paper.

[10] Jensen, M. (1993) The Modem Industrial Revolution, Exit and the Failure of Intemal Control Systems. Joumal of Finance, No. 48, 831-880.

[11] Bonnier and Bruner (1989) An Analysis of Stock Price Reaction to Management Change in Distressed Firms. Journal of Accounting, Journal of Accounting and Economics, No. 11, 95-106.

[12] Suchard, J.A., Singh, M. and Barr, R. (2001) The Market Effects of CEO Turnover in Australian Firms. Pacific-Basin Finance Journal, 9, 1-27. http://dx.doi.org/10.1016/S0927-538X(00)00032-9

[13] Quan, X.F. and Wu, S.N. (2009) The Wealth Effect of Long-Term Tenure of Chairman and Its Impact on Economic Management. Economic Management, No. 8, 119-125.

[14] Qiao, K.Y. (2013) The Reason, Influence and Behavior of the Listing Corporation. Journal of Shanxi University of Finance and Economics, No. 4, 72-86.

[15] Wen, Y.C. and Duang, Y.B. (2013) Gem Executives Leave an Empirical Analysis of the Price Impact Event. Securities Market Herald, No. 7, 31-43.

[16] Pi, L.L. and Lowe, J.L. (2005) Analysis of Chinese listed firm performance and CEO turnover. Gansu Province Social Sciences, No. 3, 203-206.

[17] Zhang, M. (2011) Research on the Behavior of China Listing Corporation. Fudan University, Shanghai. 